\title{
PRIMARY SCHOOL SYSTEM IN JAVA BEFORE AND UNDER JAPANESE OCCUPATION (1940-1944)
}

\begin{abstract}
Murni Ramli ${ }^{1}$
ABSTRACT

Primary School before and during the Japanese occupation of Indonesia has not been studied comprehensively due to the paucity of authentic data. The Japanese military document called 'Jawa ni okeru bunkyō no gaikyō' has served as an important source in this field. This study analyzes the alteration of primary school and its re-establishment process following the example of the educational system employed in imperial Japan. The number of primary schools has been reported to decline dramatically - either the number of schools or that of the students. However, we[who?] found that the number of primary schools did not significantly decrease, and, even more, the number of students increased in Java. One teacher two classes system and the one room two classes were introduced in response to the teacher shortage. The curriculum had been Japanisized through introducing new subjects such as Japanese language, spirit/mental education, physical education and vocational activities. Japanese primary school emphasizes practical education unlike the Dutch system which merely fosters and nurtures the academic side.
\end{abstract}

Key words : Primary school, educational system, Japanesse occupation

\section{Introduction}

Japanese occupation of Indonesia lasted for only three years and a half, but it brought in some important educational policies which persist and still can be found today. We can mention here, for example, the 6-year primary, 3-year middle secondary school, and 3-year upper secondary school known as 6-3-3 single track system. The physical education or physical exercise (called taisō) routinely practiced in the morning at the same time in the whole country during the Japanese period is argued to be the origin of Senam Pagi (morning physical exercise) which became a mass physical activities compulsory in all schools and government institutions during the Soeharto era.

R. Thomas Murray has revealed some policies pursued by Japanese military in Indonesia, i.e. 1) Removing Dutch language at schools, 2) Forbidding using and teaching English and French in secondary school on the grounds that

1 Dr. Murni Ramli, lecturer at Graduate School of Education and Human Development Nagoya University, Japan. Her article has ben reviewed by Prof. Dr. Said Hamid Hasan, M.A. (Universitas Pendidikan Indonesia) and Prof. Dr. Asmawi Zainul, M.Pd. (UPI) For the academic affairs, the writer can be contacted by E-mail : moernier@gmail.com 
it was 'the language of enemy' (Nasution (1995) ${ }^{2}$, 3) Teaching Japanese language at primary and secondary schools, 4) Accrediting Malay/Indonesian language as the national language used in schools and in administrative matters. 5) Forcing physical activity, and intensifying the military exercise at high school, 6) Introducing a handwork or project work which would be required for upholding and sponsoring the war, could contribute to a self sufficiency of daily needs as well. For example, growing vegetables, fish or husbandry, 7) Reorganizing some of the Dutch public high schools into vocational schools ${ }^{3}$. 8) Abolishing the teaching of Dutch and European history and substituted them with the history of Asia, Japan and Indonesia (Thomas 1966).

Those statements were approved by some authors, but there has been no effort to clarify and analyze them due to the lack of authentic data. Most studies on education under Japanese militarism in Indonesia extend only to policy matters, which mostly highlighted the benefit and eminence of single track (6-3-3), the introduction of Indonesian language as a formal subject at school and common language in administration too. Those policies are noticeable easily because it was contrasting the Dutch school system, which was run discriminatively based on social class and ethnicity. Japanese system offered more opportunities to access the education for all.

The paucity of authentic data on education in the era of Japanese occupation (1942-1945) in Indonesia has been an obstacle to undertake intricate analysis and down reaching study in. There is also an impediment regarding the language. Most of Japanese military documents are written using old Japanese grammar and characters. Of course it is understandable and apprehend only by Japanese scholars. There are many Japanese historians focusing on the Japanese occupation in Southern Asia, but only a few scholars interested in education. Aiko Kurasawa can be mentioned as the most productive writer, focusing on social change and farmer society in Java, including the culture and educational policies, pertaining some issues on education in her famous books, Nihon senryo moto no jawa nōson no henyō (which had been translated into Bahasa Indonesia as "Mobilisasi dan kontrol: Studi tentang perubahan sosial di pedesaan Jawa, 1942-1945”.

She was lucky to get the secret document about the educational policy of Japanese military in Java in 1943 from Dr. Leonard Blusse, a Dutch historian who got it from a Dutch man fought during 1945-1959. This document titled "Java ni okeru bunkyō no gaikyō" (Japanese Educational Policy in Java, hereinafter called bunkyō no gaikyō) and as a part of "Nanbō gunsei kankei shiryō" (The documents related to Southern Military Rule). The document describes the educational

${ }^{2}$ French, German, and English were compulsory subjects both in secondary and primary level as well, particularly the elite schools for European and elite society. But, it taught mostly in ELS, the primary school for European, and shorter period in HCS and HIS.

${ }^{3} \mathrm{High}$ school under Dutch colonialism purposed to educate civil servant who will be assigned in government office. Japanese military thought they did not need more officers, but demanding more labors or soldiers as well for war aim. 
administration, educational policies, school system, school curriculum, text books, both general school and the vocational school in Java in academic year 1943/1944 or Japanese calendar, Showa 18/19. It contains remarkably important data which can be said as lightening the road to deeply analyze the educational practices in the given time.

Based on this document, this study will analyze and discuss further what many scholars discourse about the introduction of single track system in Indonesia during 1940-1943. However, in this paper, I do not go further on discussing schooling system entirely, but I will concentrate on the analyzing the process of reopening, reconstructing the curriculum, and the statistics of primary schools. Primary school has been chosen due to the fact that under the Dutch period it was established as the most discriminated institution, separated ones for elites and for commoners. The term of primary school in this study refer to what is recently known in Indonesia's educational system as Sekolah Dasar.

For that purpose, the following points are examined:

1. It is an intricate policy to unify various primary schools during Dutch colonial era. Some papers describe that Japanese authority abolished all primary schools and established a 6-year primary school. But, abolishment and renewal of the school buildings, then directly in a short time introduced the new system which was definitely contradicted with the old one was impossible in such unstable political situation in 1942. Then, how did Japanese military reorganized the multi-track educational system into the single-track?

2. Scholars generally delineate that the number of schools under Japanese authority had dramatically declined, either in elementary or in secondary level (Mestoko 1985:139). However, on the positive side, it was also mentioned that Japanese military employed the mass and a non discriminative education system which permitted all people to access the schools without any preferences. How could Japanese military manage both issues aptly?

3. The study of Western culture and language was abolished, Japanization had been introduced, and Indonesian language was taught in all schools. However, in the period of independence, Ki Hajar Dewantara as the first Ministry of Teaching and Education decided to adopt Dutch curriculum instead of Japanese military's for primary schools for independent Indonesia. Thus, there should be some considerations. Therefore, we have to scrutinize the curriculum structure introduced by Japanese military and compare it with the Dutch's. For placidly actualizing the new system, how Japanese military quickly prepared teachers and provided the Japanese and Indonesian textbooks in the short period?

\section{Organizing Single Primary School}

School organization during the Japanese occupation was applied accordingly to the one in Imperial Japan, although slightly differing in the school type. Education in Dutch East Indies under Japanese militarism had completely 
divided into three levels, namely shotōkyōiku (primary education), chūtōkyōiku (secondary education), and kōtōkyōiku (higher education) (Fig.1).

However, as reported in bunkyō no gaikyō, the schooling was not conducted as co-education. Assuming that the boys and girls have differences in biological aspects, interests, and the vocation that should be learned, the military authority decided to separate the education for boys and girls. This policy differs from the Dutch system, where in certain level, Dutch school was conducted as coeducation, but there was also single-sex school, such as the Vervolgschool ${ }^{4}$.

Most of literature referred the Kokumingakkō (People School, translated in Indonesian as Sekolah Rakyat) as the only type of primary school during the Japaneseoccupation. Butaccordingtobunkyōnogaikyō,chaptertwo,gakkōkyouiku (formal education), part two, kankōritsushokyōiku (Public and Private Schools), there were some models of Kokumingakkō. First, the Kokumingakō which provided both elementary course (shotōka) and comprehensive course (futsūka), each conducted in three years. Second, there was Shotōkokumingakkō (translated as Sekolah Pertama), which only provided three years elementary course. Third, there was Kokumingakko which only offered comprehensive course, namely Futsūka kokumingakkō. While, Shotōkokumingakkō had another types, i.e. 4year school, and the Kokumingakkō also varied, i.e. 5-year, and 7-year schools. In academic year Showa 19 (equal to 1944) all Shotōkokumingakkō was harmonised into a three-year school, and all Kokumingakkō was unified as a six-year school (bunkyō no gaikyō : pp.34-35).

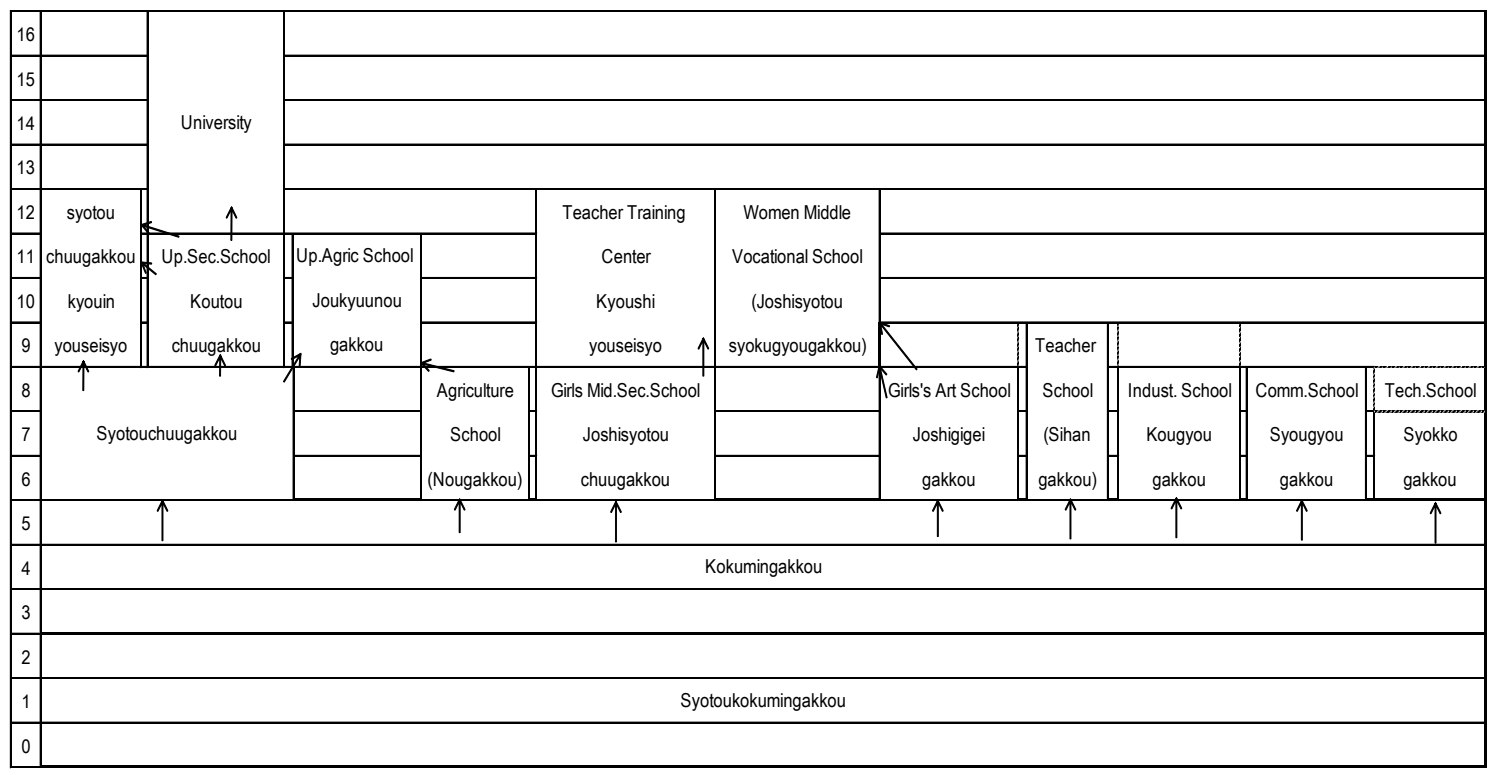

Figure 1. The Educational System under Japanese Occupation? (1942-1945) Source : Bunkyō no gaikyō:12

${ }^{4}$ There was Meiserjsvervolgschool (Vervolgschool for girls) as mentioned in bunkyō no gaikyō. 
It should take considerable time to completely reorganize the different Dutch's primary schools, then simplify as 6-year primary school. But, Japanese military had strong intention, worked quickly and systematically as can be noticed from the number of ordinances and policies set up during the two years of occupation. If we agree with Pusponegoro and Notosusanto (1995:3-14), we can say that Japanese militarism started in $8^{\text {th }}$ March 1942, the day when they landed in Tarakan, Kalimantan. Then, the first ordinance on reopening the school was enacted on April $29^{\text {th }}$, 1942, or less than two months after the arrival, the military authority in Java acted quickly to disseminate the new system. According to bunkyō no gaikyō, there were eight ordinances enacted in 1942 and about 30 decrees in 1943 issued the matters of schooling system (bunykō no gaikyō, pp.112-114). On the contrary, the Dutch just started to be seriously built the schools for Indonesian people at the end of the $19^{\text {th }}$ century, decades after her arriving, and completely constructed the school system in 1920, when high school for the commoners, called AMS, was finally established. Hence, thinking that it was no more than two years, what Japanese military did in the field of educational policies should be considered as remarkable.

The 3-year Villageschool, 2-year Vervolgschool, 5-year Tweede Klassen School, 5-year Schakel School, and 7-year Europeesch Lagere School(ELS), Hollandsch Inladsche School(HIS), or Hollandsch Chineese School(HCS) were various primary schools remained till the end of Dutch colonialism in 1941. Those various primary schools had been grouped into two kinds of school as mentioned above. According to the Act number 3 enacted in $29^{\text {th }}$ April 1942 about re-opening the school's, the Shotōkokumingakkō was a restructuring of Desa Sekolah (Villageschool), Samboengan Sekolah (Vervolgschool), Kelas doeasekolah(Tweede Klassen School), and Meisjesvervolgschool(Vervolgschool for girls). It means that the rest, i.e. Schakelschool, HIS, HCS, and probably ELS was reopened as Kokumingakkō.

This classification most probably did not divide the schools into those for elites and those for commoners, but it merely applied based on the school term and class instructional language. Most of the schools in Java which categorized as Shotōkokumingakkō used local languages, such as Malay, Jawa, Sunda, and Madura as class instructional language.

We can also notice that vocational schools or technical training provided in the Dutch period as the continuation of Volkschool or Twedee klassen school had been abolished too. Primary schools provided general education only, and equipped with some technical or vocational subjects were separated for boys and girls.

The students who had finished Shotōkokumingakkō and the students who had completed the 5-year Kokumingakkō did not receive the graduation certificate (sotsugyōshōmeisho), but they obtained the completion diploma or certificate (shūgyōshōsho or shōmeisho). However, those who had graduated from 6-year or 7-year Kokumingakkō were entitled the graduation certificate 
(sotsugyōshōmeisho). It means that before unifying various primary schools into six-year school system, Japanese military government first approved and admitted students who were studying in various Dutch schools. If they finished the education sooner than in 6-year school, they got the completion diploma, but not the graduation certificate. Then, what was the differencebetween these certificates? It can be presumed that the completion diploma only approved as for entering workforce and on the contrary, the graduation certificate was a requirement for enrollment into higher grade or school. Thus, students accomplished the Shotōkokumingakkō had to study one year more in Kokumingakkō in order to get the graduation certificate as a "green card" for enrolling the secondary schools.

This dual primary school system, i.e. Kokumingakkō and Shotōkokumingakkō was adopted by the Badan Pekerja Komite Nasional Indonesia Pusat (BP-KNIP) in its proposal on 1946 as cited by Tilaar (1995:72). However, the Panitya Penyelidik Pengajaran in 1947 prompted the single 6-year Sekolah Rakyat and abolished other types. Here, we can surmise that the primary school system in the early period of Indonesia's independence and the next period was originally adopted from the system introduced by Japanese military.

\section{Analyzing the Decline of Schools and Student Number}

Some historical literatures mentioned that the number of schools during the Japanese occupation declined dramatically. For example Mestoko has written as follows:

.... primary school decreased from 21,500 units to 13,500 , and secondary schools decreased from 850 to 20 units. Similarly, primary school students also decreased 30\%, while secondary school students dropped off 90\%. Number of primary school teachers dropped off $35 \%$ and secondary school teachers decreased 95\%, thus, only $5 \%$ actively worked ... (Mestoko 1985:139, see also Djoyonegoro,1996,p38) )

Unfortunately, Mestoko and other scholars did not provide the source of the data and unfortunately they do not enclose also the accurate period of the data. Thus, it is uncertain whether the decline took place at the end of Japanese occupation (1945) or in the middle of it (1943 or 1944). To analyze the growth and the decline of primary schools under Japanese occupation, we have to focus on situation both right before the Japanese occupation (1940-1941) and the time after (1945). However, it is effortful work due to inadequate data describing the situation of the whole country statistically. Statistics of Dutch East Indies education in 1940 might be an estimation of 1930's data, because the census planned to handle in 1940 was cancelled due to Germany's attack of the Netherlands before the WWII.

Here we use the most commonly cited data figuring education in Dutch East Indies in 1940 compiled by Van der Wal (1963). According to this data, the number of primary schools in 1940 was 21,255 units. This number of schools was 
an accumulation of the European Primary School (ELS), the Special School, the Dutch Chinese School (HCS), the Bumiputera-Dutch School (HIS), the Tweedee School, the Volkschool, the Vervolgschool, and the Schakelschool (Table 1).

Bunkyō no gaikyō page 12 shows the number of student attending primary school in 1941, through this we can trace that the number of student had decreased from $2,348,854$ in 1940 into $1,597,170$ students in 1941 in the whole country (Table 1).Unfortunately, the data does not include the number of school.

Tabel 1 School and Student Number in Indonesia (1940-1945)

\begin{tabular}{|c|c|c|c|c|}
\hline Institution & School No. & Student No. & School No. +/- & Student No. +/- \\
\hline \multicolumn{5}{|l|}{ Prelude Japanese Occupation (1940) } \\
\hline Europeschee Lagere School （ELS) & 292 & 47,282 & & \\
\hline Special School (Sekolah Khusus) & 15 & 4,589 & & \\
\hline Holland Chinese School (HCS) & 110 & 25,467 & & \\
\hline Holland Inlandsche School (HIS) & 285 & 71,976 & & \\
\hline Schackel School & 52 & 6,011 & & \\
\hline sub total & 754 & 155,325 & & \\
\hline Tweedee Klasse School & 34 & 9,759 & & \\
\hline Volkschool & 17,718 & $1,896,374$ & & \\
\hline Vervolgschool & 2,749 & 287,126 & & \\
\hline sub total & 20,501 & $2,193,259$ & & \\
\hline Total (1940) & 21,255 & $2,348,584$ & & \\
\hline \multicolumn{5}{|l|}{1941} \\
\hline Chinese Lagere School (CLS) & No & 3,232 & & \\
\hline Special School (Sekolah Khusus) & No & 3,633 & & \\
\hline Holland Chinese School (HCS) & No & 19,640 & & \\
\hline Holland Inlandsche School (HIS) & No & 52,305 & & \\
\hline Schackel School & No & 4,418 & & \\
\hline sub total & & 83,228 & & $(-72,007) \quad(46.4 \% k)$ \\
\hline Tweedee Klasse School & No & 10,048 & & \\
\hline Vervolgschool & No & 217,808 & & \\
\hline Volkschool & No & $1,286,086$ & & \\
\hline sub total & & $1,513,942$ & & $(-679,317)(30.9 \% k)$ \\
\hline Total (1941) & & $1,597,170$ & & $(-751,414)(32.0 \% k)$ \\
\hline \multicolumn{5}{|l|}{ Japanese Occupation (1943) } \\
\hline Kōritsu kokumingakkō (Public) & 2,102 & 467,618 & & \\
\hline Shiritsu kokumingakkō (Private) & 766 & 121,407 & & \\
\hline sub total & 2,868 & 589,025 & $(+2,114)(280.0 \% \pi)$ & $(+495,749)(533 \% \pi)$ \\
\hline Kōritsu shotōkokumingakkō (Public) & 11,078 & $1,793,735$ & & \\
\hline Shiritsu Shotōkokumingakkō (Private) & 401 & 49,969 & & \\
\hline sub total & 11,479 & $1,843,704$ & $(-9,022)(44.0 \% k)$ & $(+339,810)(22.6 \% \pi)$ \\
\hline Total (1943) & 14,347 & $2,432,729$ & $(-6,908)(32.5 \% \boldsymbol{k})$ & $(+835,559)(52.3 \% \pi)$ \\
\hline \multicolumn{5}{|l|}{ After Japanese Occupation (1945) } \\
\hline Elementary School (Sekolah Rakyat) (1945) & 15,069 & $2,523,410$ & & \\
\hline Total (1945) & 15,069 & $2,523,410$ & $(+722)(5.0 \% \pi)$ & $(+90,681)(3.7 \%$ 入) \\
\hline
\end{tabular}

Source : Data in 1940 retrieved from S. L. Van der Wal (ed) Het Onderwijsbeleid in Nederlands -Indie 19001940, 1963 quoted by Djoyonegoro (1996:62-68), and rearranged by writer. Data is accumulation of public and private school. Data in 1941 retrieved from bunkyō no gaikyō (p.45) cited by Kurasawa (1991).Data on Japanese occupation era cited from bunkyō no gaikyō (p.44) cited by Kurasawa (1991). And data in 1945 retrieved from Djoyonegoro (1996:142)

In contrast, the data of schooling published by the Japanese military in 1943 lists that the number of public and private Kokumingakkō was 2,868 units, and Shotōkokumingakkō was 11,479, both public and private. It means, 
in the Java Island itself, there had been 14,347 primary schools existed in the year 1943/1944. The number of students of primary schools at the given time was $2,432,729$ students. Supposed that the schools in Java was almost 90\% of total schools in the whole country at the time, we can nearly estimate that the number of primary schools in the entire country increased by about $270 \%$ compared to the data in 1940 or 1941 by Van der Wal (Table 1).

Here is also a need to scrutinize the data presented in bunkyo no gaikyō as accredited both the Kokumingakkō (public and private) and the Shotokokumingakkō. In that context, according to definition of Kokumingakkō as cited above, we can roughly surmise that the 14,347 units of primary school mentioned in this document, were the re-establishment of Volkschool, Vervolgschool, Tweede Klassen School, Schakel School, ELS, HIS and HCS.

But, if we compare these data with the one presented by Van der Wal, there is some mismatch of the schools' statistics from 1940 to 1943. According to Van der Wal, the number of schools classified by Japanese military as Kokumingakkō only existed 754 units in the entire country in 1940. However, according to bunkyō no gaikyō, the number of Kokumingakkō in 1943 was 2,868 units in Java alone. It means that there was an establishment of at least 2,114 units of new 6-year primary schools within three years. On the contrary, the number of what Japanese military called as Shotōkokumingakkō decreased from 20,501 in 1940 to 11,479 in 1943 or declined 9,022 units within three years. Supposed that 2,114 units of 6-year primary schools were re-opening of Shotōkokumingakkō or were a result of merger of Volkschool and Vervolgschool, and reopening the Tweede Klassen School, we can roughly summarize that Japanese military had abolished or closed about 6,908 units of Volkschool and Vervolgschool, or equal to $32.5 \%$ of varied primary schools.

Meanwhile, the report published by the Educational Research and Development Institution (BALITBANG) of the Ministry of Education and Culture in 1979, quoted by Djoyonegoro (1996:142) denotes that the primary schools in Indonesia in 1945 was 15,069 units, and there were 2,523,410 students enrolled. If we conjecture that the Indonesian government could not build new schools after regaining independence in August, 1945 due to unstable political and economic situation, we can ascertain that the 15,069 units of primary schools in 1945 represented the 6-year Kokumingakkou which was introduced by Japanese military in 1944.

The number of primary school students in Java in 1943 was 607,104 students, which can be clarified as 130,857 students belonging to Kokumingakkō, and 476,247 students to Shotōkokumingakkō. From this fact, we can assume that the number of student who able to fulfill the requirement of enrolling the secondary schools was only $21.6 \%$.

It is difficult to prove what Mestoko argued as the decline of about $30 \%$ of primary school student during the Japanese occupation. As can be noticed that the number of students in 1940 was 2,348,584 students, and in 1943 there was 
$2,432,729$ students (in Java only). It means here, there was increasing of students enrolled the primary school within three years either in Java or in outer islands. We can also notice that the number of student was significantly increased from 1943 into 1945 (90,681 students).

However, there is an interesting fact that the number of primary student dramatically declined from 1940 into 1941. Supposing that the data is correct, there should be a mismatch regarding about 751,414 students. This fact should be questioned, on what happened in Dutch East Indies during 1940-1941? And what happened with about $32 \%$ primary school students?

The Second World War (1941-1942) which is regarded as one of the largest destructive conflicts in our history can be a reason of declining number of students in 1941. The population of Dutch East Indies in 1940 was not precisely known, since the previous census conducted by Dutch East Indies government was in 1930, and due to the attack of Germany to Netherlands, the population census which planned to be handled on 1940 had been postponed. Therefore, what presented by Dower (1986:296) in his book, "War Without Mercy" ,i.e. there were about 69,435,000 people in Dutch East Indies in 1939, should be not an actual population, but an estimation based on population growth founded in census 1930. Van der Eng (2002) reported a good comparative data from various resources and made detailed analysis regarding the population growth of Indonesia in 1930-1961. According to Volkstelling 1930 cited by Van den Eng, the population of Dutch East Indies in 1930 was 60.98 million. Van den Eng based on the population growth in Java and outer islands estimated that in 1930, the population of Indonesia was 60.993 million and in 1942 was 73.522 million. It seems that there was no declination of population in Indonesia during the WW II.

However, according to Dower the civilian deaths in Dutch East Indies as victims of WW II were about 3.03 million to 4.03 million (Dower 1986:296). Gruhl (2007) presented similar estimation that the civilian death due to the war and Japanese occupation was three million Indonesians and 30,000 interned Europeans. United Nations reported, three million for Java alone, and one million for the outer islands. Those victims include men killed or having died from disease, hunger and lack of medical treatment.

The decrease of primary school student population in 1941 might have beeen due to the war, since as we can notice from Table 1, about $43.5 \%$ primary schools actually were the schools dominated by European or elites commoners, and $31.1 \%$ were schools attended only by the commoners. We can assume that many Europeans had to go back to their countries by reason of Japan's propaganda to get rid of all western impacts in Dutch East Indies in the earlier of her occupation.

Based on discussion above, we can conclude that schooling under the Japanese military was by necessity decreased due to the merger of 3-year and 5 -year schools that existed in 1940 into a unified 6-year Kokumingakkō. Therefore, 
it might be indubitably assumed here, that scholars have different perceptions of the term "primary school" in two periods, i.e. Dutch colonial era and Japanese occupation era. In concrete speaking, we can say that scholars defined the primary schools in 1940 as the accumulation of varied 3-year, 4-year, 5-year, and 7-year schools in the Dutch colonial. And, they narrowly were determining the school in 1942 as 6-year Kokumingakkō without counting the Shotōkokumingakkō. Hence, it was noticeable that the number of primary school in the Japan occupation period was lower than under the Dutch. Instead of building the new schools, Japanese military tended to merge the existing various less than 6-year primary schools into one type of Kokumingakkō.

The increasing of primary school students during the Japanese occupation has also been proven. Though the number of schools declined, the number of commoners who could access the primary education increased. Implementing the non discriminative education can be regarded as a positive side of Japanese military policy.

\section{Anticipating Teacher Shortage in Primary School}

The "Japanization" was expanded either in political or social aspect extensively, and we can say that education became the important starting point to totally disseminate in society. In the field of education, employing Japanese language, Japanese history, spirit, and other related subjects came with some consequences such as, preparing as well the human resources working in.

For that purpose, training the commoner teachers to acquire the Japanese learning culture, the spirit was necessary, and in some cases sending Japanese teachers to Indonesia became an important approach. As a consequence of Japanization, all European teachers were expelled, and just before the Japanese army arrived, some of them had already joined the Dutch army against Japan.

To anticipate the lack of teachers in primary school in Java, the military since April, ${ }^{\text {st }} 1944$ applied the Nibukyojjusei (one teacher two classes) and the Fukushikikyōju (one room two grades). The implementation of this policy in Java as figured in Table 2.

Java was divided into 20 provinces (Kurasawa uses residence), which can be grouped into first, regions located in west part of the island, i.e. Banten, City of Djakarta, Djakarta Province, Bogor, Priangan, and Tjirebon. Second, the regions located in central Java, i.e. Pekalongan, Banjouemas, Semarang, Pati, Kedoe, Soerakarta, and Djokjakarta. And the third are regions located in east Java, i.e. Madioen, Bodjonegoro, Kediri, Malang, Besoeki, and Madoera.

Priangan had highest classroom of Kokumingakkō, and Madoera was the lowest, but central Java highest among other part of the island. The number of Kokumingakkō's classroom entirely Java was 9,569 and the number of grades was 10,849 . It means, there was 1,280 grades that had to use the same classroom. While the number of teacher was only 8,795 teachers, there was shortage of about 
2,054 teachers. However, when one teacher for two classes system was employed in 2,237 cases, there were about 183 overlapping cases. However, when we think that those teachers might have taught only one subject, for example Japanese language or music, the overlapping was probably none.

In term of Shotōkokumingakkō, the number of grades almost doubled the number of classroom. 19,211 classrooms had to be used together by two grades. The number of teacher was only 23,668 persons, then, if one grade one teacher system applied, teacher shortage was 18,511 persons. However, there were 13,163 cases of nibukyōjusei introduced, means there were only 26,326 grades covered. The rest of grades (16,853 grades), each was taught by one teacher.

Since the languageinstructor for grade 5 and 6 was Japanese it was necessary to train the teachers to master Japanese language, or sometimes government had to send Japanese teachers as well. Even though grade 4 was instructed in Malay language and the lower grades still allowed the use of local language, subjects like shūshin used Japanese's textbook, hence it was still urgent to prepare teachers mastering Japanese.

Table 2 Implementation of Nibukyōjusei in Java (1943)

\begin{tabular}{|l|c|c|c|c|c|c|c|c|}
\hline \multirow{2}{*}{ Name of province } & \multicolumn{9}{|c|}{ Kokumingakkō } & \multicolumn{3}{c|}{ Shotōkokumingakkō } \\
\cline { 2 - 9 } & $\begin{array}{c}\text { No.of } \\
\text { classroom }\end{array}$ & $\begin{array}{c}\text { No. of } \\
\text { grade }\end{array}$ & $\begin{array}{c}\text { No. of } \\
\text { teacher }\end{array}$ & $\begin{array}{c}\text { No.of } \\
\text { nibukyōjusei }\end{array}$ & $\begin{array}{c}\text { No.of } \\
\text { classroom }\end{array}$ & $\begin{array}{c}\text { No. of } \\
\text { grade }\end{array}$ & $\begin{array}{c}\text { No. of } \\
\text { teacher }\end{array}$ & $\begin{array}{c}\text { No.of } \\
\text { nibukyōjusei }\end{array}$ \\
\hline Banten & 224 & 250 & 97 & 67 & 541 & 818 & 479 & 197 \\
City of Djakarta & 220 & 230 & 224 & - & 179 & 344 & 183 & 28 \\
Djakarta Province & 184 & 166 & 159 & - & 584 & 921 & 561 & 22 \\
Bogor & 298 & 328 & 294 & 66 & 1,039 & 1,610 & 1,009 & 1,212 \\
Priangan & 1,690 & 2,189 & 1,675 & 232 & 2,039 & 3,508 & 1,998 & 916 \\
Tjirebon & 298 & 328 & 294 & 138 & 1,215 & 2,220 & 1,449 & 968 \\
\multicolumn{1}{c}{ Sub total } & 2,914 & 3,491 & 2,743 & 503 & 5,597 & 9,421 & 5,679 & 3,343 \\
Pekalongan & 514 & 514 & 424 & 230 & 1,617 & 3,165 & 1,606 & 530 \\
Banjoemas & 444 & 492 & 415 & 368 & 1,626 & 3,327 & 1,781 & 2,062 \\
Semarang & 400 & 408 & 346 & 217 & 1,366 & 3,276 & 1,337 & 669 \\
Pati & 276 & 508 & 251 & 85 & 1,264 & 2,579 & 1,282 & 678 \\
Kedoe & 793 & 971 & 718 & 239 & 2,122 & 3,696 & 2,097 & 539 \\
Djokdjakarta & 965 & 951 & 869 & 18 & 1,454 & 1,874 & 1,269 & 563 \\
Soerakarta & 475 & 332 & 445 & 36 & 882 & 1,687 & 862 & 700 \\
\multicolumn{1}{|c|}{ Sub total } & 3,867 & 4,176 & 3,468 & 1,193 & 10,331 & 19,604 & 10,234 & 5,741 \\
Madioen & 501 & 520 & 462 & 20 & 1,586 & 2,000 & 1,580 & 440 \\
Bodjonegoro & 296 & 334 & 242 & 52 & 991 & 1,651 & 959 & 586 \\
Kediri & 832 & 1,164 & 773 & 372 & 1,969 & 3,968 & 1,940 & 1,652 \\
Malang & 336 & 365 & 336 & 18 & 1,026 & 1,981 & 1,025 & 439 \\
Soerabaja & 385 & 382 & 354 & 66 & 1,019 & 1,682 & 864 & 450 \\
Besoeki & 256 & 263 & 246 & 3 & 925 & 2,068 & 889 & 474 \\
Madoera & 182 & 154 & 171 & 10 & 524 & 804 & 498 & 38 \\
\hline \multicolumn{1}{c}{ Sub total } & 2,788 & 3,182 & 2,584 & 541 & 8,040 & 14,154 & 7,755 & 4,079 \\
\hline \multicolumn{1}{c}{ Total } & 9,569 & 10,849 & 8,795 & 2,237 & 23,968 & 43,179 & 23,668 & 13,163 \\
\hline
\end{tabular}

Source : Kurasawa (1991:37). The subtotal is added by author.

For acquiring Japanese, there was also a Japanese language school opened in each province around the island. Those schools trained officers who were 
assigned in government offices or worked as teachers. In $27^{\text {th }}$ July 1943, the first Japanese Proficiency Test was conducted on five levels. Most participants came from Kedu, Priangan, Kediri, which are more developed than other regions. About 20,000 participants registered, and 14,200 passed the test (bunkyō no gaikyō, p.25).

\section{Primary School Curriculum}

\section{a. Dutch Curriculum}

Ignoring the weekly hours, Nasution (1995) roughly describes the composition of weekly subjects taught in varied Dutch primary schools (Table 4).

Table 4 Primary School Curriculum under Dutch Colonialism

\begin{tabular}{|c|c|c|c|c|c|}
\hline ELS & HIS & HCS & Eersteeschool & Tweedeschool & Volkschool \\
\hline $\begin{array}{c}\text { Compulsory Subject } \\
\text { Reading } \\
\text { Writing } \\
\text { Arithmetic } \\
\text { Dutch } \\
\text { History } \\
\text { Geography } \\
\text { Supplementary Subject } \\
\text { French } \\
\text { German } \\
\text { English } \\
\text { World History } \\
\text { Mathematics } \\
\text { Art/Vocational } \\
\text { Physical Education }\end{array}$ & \begin{tabular}{|} 
Reading \\
Writing \\
Arithmetic \\
Dutch \\
Geography \\
Local language \\
Malay \\
.Jawi ${ }^{\text {a }}$ \\
German \\
English \\
World History \\
Mathematics \\
Art/Vocational \\
Physical Education
\end{tabular} & \begin{tabular}{|c|} 
Chinese \\
English \\
French \\
Dutch \\
Arithmetic \\
Reading \\
Writing \\
History \\
Geography \\
World History \\
Mathematics \\
Art \\
Physical Education
\end{tabular} & $\begin{array}{c}\text { Reading \& Writing } \\
\text { in local language } \\
\text { Malay } \\
\text { Arithmetic } \\
\text { Indonesian Geography } \\
\text { Dutch } \\
\text { Science } \\
\text { Local History } \\
\text { Drawing } \\
\text { Land Measurement } \\
\text { Singing }\end{array}$ & \begin{tabular}{|} 
Malay \\
Arithmetics \\
Drawing \\
Singing \\
Geography \\
Science \\
Local Language \\
Art
\end{tabular} & 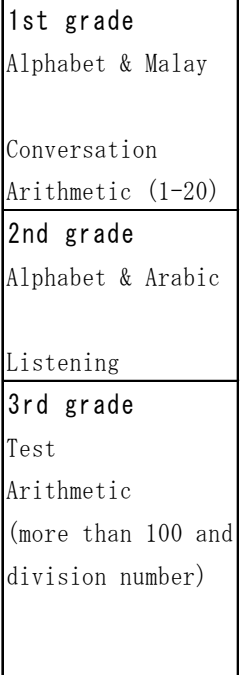 \\
\hline
\end{tabular}

Source : Nasution (1995:50-121)

Schools for commoners were principally offering the very basic education as we can see in Volkschool, where students learned what is assumed to be basic abilities for children recently enrolled in Indonesian kindergartens i.e. reading, writing (in Malay and Arabic) and counting numbers no further than hundred. Tweede Klassen School offered more advanced subjects, such as drawing, singing, geography, science, and art. Local language had been instructed replacing the Arabic.

As the extension of Volkschool, or parallel to Tweedeschool, Vervolgschool provided some advanced subjects, i.e. geography, science, drawing, singing, and physical exercise. Vervolgschool was exclusively divided as one for ethnic Malays and another for non Malays, which differed in setting the Malay language as a foreign language or not. Introducing Dutch as a part of language education was conceded as a way to distinguish school for elites and for commoners. Dutch 
was taught 8-10 hours per week in Vervolgschool, and it might be longer in Eersteeschool (later changed to HIS), HCS, ELS, and Schackelschool.

School for elites also can be identified by its language education. German and English was introduced in ELS, HCS, and HIS, but French was taught only in ELS and HCS which tended to discriminate between indigenous commoners (the bumiputera) and the migrant commoners (Chinese, Middle East, Africa, etc.).

Various languages taught in primary school were practically unnecessary for daily life, since most of commoners did not pursue higher education. However, since many graduates of ELS continued to HBS, Gymnasium or Lycea in the Netherlands, it was logical that they needed to master those European languages as basic tools for acquiring the learning background. But since none or significantly few of commoners and even the elites went to higher level, it was wasteful to force them learn such various Western languages.

History also became an important subject which pinpointed the school for elites and commoners, as we can notice that history had been taught in HIS, HCS, and ELS, both Dutch and World history.

\section{b. Japanese Curriculum}

Curriculum plan and the content of schooling under Japanese military had been changed mostly by stressing the language and more vocational subjects. The revised curriculum which was based on the Policy number 39 enacted in 11 May 1943 had to be implemented fully either in public or private Kokumingakkō at least until July $1^{\text {st }}$ in the same year. As can be noticed in Table 5 , the weekly learning hours were reduced, but the subjects increased and varied. The new subjects were $k \bar{s} s a k u$ (carpenter or woodwork), sagyō (handwork), jigyō (business), and kasei (housekeeping) for girls.

It is interesting to notice that the title of the subject was also altered later, i.e. sūgaku (mathematics) changed to sansū (arithmetic), dōtoku (moral) into shūsin (spirit,mental), shukō (handmaking) became kōsaku (carpenter), kagaku (natural science) changed to rika (science), and finally eisei (health) and taisō (physics exercise) integrated as one subject called tairen (physical education or sports). However, due to the lack of data about subject content, we cannot prove whether the content of those subjects changed as well.

The entire revised curriculum was reduced to 34 hours, where 4 hours were cut in each grade, except grade 1 and grade 3 which shortened 6 and 10 hours respectively. School started at 8:30 am and finished at 13:20 pm, without lunch break, but each lesson was separated by 10 minutes break (Table 6), and one hour lesson conducted in 40 minutes. The system differs with what is employed in Japan modern schooling nowadays, which provides lunch break around 12:00 noon $^{5}$, and 45 or 50 minutes per lesson. But, it is similar in the starting time and the number of lesson per day.

${ }^{5}$ Learning hours differ depend on schools and the policy of the Board of Education in each district or municipal 
HISTORIA:

International Journal of History Education, Vol. XI, No. 1 (June 2010)

Table 5 Old and New Curriculum of Kokumingakkō

\begin{tabular}{|c|c|c|c|c|c|c|c|}
\hline \multicolumn{2}{|c|}{ Subject } & \multicolumn{6}{|c|}{ Weekly learning hours } \\
\hline Old Curriculum (1942) & New Curriculum (1943 ) & \multicolumn{6}{|c|}{ Old } \\
\hline \multirow{4}{*}{$\begin{array}{l}\text { Moral (dōtoku) } \\
\text { Japanese (nihongo) } \\
\text { Local language (chihōgo) } \\
\text { Mathematic (sūgaku) }\end{array}$} & \multirow{5}{*}{$\begin{array}{l}\text { Mental (Shūsin) } \\
\text { Japanese language } \\
\text { Local language } \\
\text { Arithmetic (sansū) } \\
\text { Calligraphy }\end{array}$} & 1grd & $2 \mathrm{grd}$ & 3 grd & 4grd & $5 \mathrm{grd}$ & 6grd \\
\hline & & 30 & 30 & 40 & 40 & 40 & 40 \\
\hline & & & & & & & \\
\hline & & & & & & & \\
\hline Calligraphy (shūji) & & \multicolumn{6}{|c|}{ New } \\
\hline Drawing (zuga) & \multirow{4}{*}{$\begin{array}{l}\text { Drawing } \\
\text { Music } \\
\text { Sports (tairen) }\end{array}$} & 1grd & 2grd & 3 grd & 4grd & $5 \mathrm{grd}$ & 6grd \\
\hline Music (Ongaku) & & 24 & 26 & 30 & 34 & 36 & 36 \\
\hline Health (eis ei) & & & & & & & \\
\hline Physic exercise (taisō) & & & & & & & \\
\hline Handmaking (shukō) & Carpenter (kōsaku) & & & & & & \\
\hline Geography (chiri) & Geography & & & & & & \\
\hline History (rekishi) & His tory & & & & & & \\
\hline Natural Science (kagaku) & Science (rika) & & & & & & \\
\hline \multirow[t]{4}{*}{ Malay (mare go) } & Malay & & & & & & \\
\hline & Work (sagyō) & & & & & & \\
\hline & Business (jigyō) & & & & & & \\
\hline & Hous ekeeping (kasei) & & & & & & \\
\hline
\end{tabular}

Source : bunkyō no gaikyō p.41

Table 6 Kokumingakkō's school hours

\begin{tabular}{|c|c|c|c|c|c|c|}
\hline \multirow{2}{*}{ Time } & \multicolumn{6}{|c|}{ Lesson Period } \\
\cline { 2 - 7 } & First & Second & Third & Fourth & Fifth & Sixth \\
\hline Start & $8: 30$ & $9: 20$ & $10: 10$ & $11: 00$ & $11: 50$ & $12: 40$ \\
Finish & $9: 10$ & $10: 00$ & $10: 50$ & $11: 40$ & $12: 30$ & $13: 20$ \\
\hline
\end{tabular}

Source : bunkyō no gaikyō p.43

The new curriculum of Kokumingakkō figured in Table 7. Grade 1 and 2 learned Shūshin, Japanese language, local language, arithmetic, physic education, music, calligraphy, woodwork, and hand drawing, or 9 subjects in total. Grade 3 learned more subjects, such as Malay language and work exercise. We can notice here that Japanese militarism traditionally kept the local language as language instruction in grade 1 and 2, just similar with Dutch policy in primary schools for commoners. It is also noticeable that lower grade spent shorter time at school.

Another characteristic is the emphasis on language education, especially Japanese language in higher grades, which took six hours per week, Malay language (mare go) 6 taught 4-5 hours per week. Interestingly, the local language was maintained in higher grades.

${ }^{6}$ Bunkyō no gaiykō sometimes used mare go and in some parts used Indonesia go to name the Indonesia language or Bahasa Indonesia. Lapian (1996) said that after April,29 ${ }^{\text {th }}$ 1945, Mare go officially named Indonesia go. 
Table 7 Primary School Curriculum under Japanese Occupation

\begin{tabular}{|c|c|c|c|c|c|c|}
\hline \multirow{2}{*}{ Subject } & \multicolumn{6}{|c|}{ Weekly lessons (hours) } \\
\hline & $1 \mathrm{st}$ & 2nd & $3 \mathrm{rd}$ & 4th & 5 th & 6th \\
\hline Spirit Education $\quad$ Shūsin) & 2 & 2 & 2 & 2 & 2 & 2 \\
\hline Japanese (Nihon go) & 3 & 4 & 5 & 6 & 6 & 6 \\
\hline Malay (Mare- go) & 0 & 0 & 4 & 4 & 5 & 5 \\
\hline Local language $\quad$ (Chihō go) & 6 & 6 & 4 & 3 & 3 & 2 \\
\hline History （Rekishi) & 0 & 0 & 0 & 1 & 1 & 1 \\
\hline Geography (Chiri) & 0 & 0 & 0 & 1 & 2 & 1 \\
\hline Arithmetic（Sansū $)$ & 4 & 5 & 5 & 4 & 4 & 4 \\
\hline Science（Rika) & 0 & 0 & 0 & 1 & 1 & 2 \\
\hline Physical Education (tairen) & 4 & 4 & 3 & 3 & 3 & 3 \\
\hline Music (Ongaku) & 4 & 4 & 2 & 2 & 1 & 1 \\
\hline Callighraphy（Shūji) & 1 & 1 & 1 & 1 & 0 & 0 \\
\hline Woodwork (Kōsaku) & 2 & 2 & 2 & 2 & 2 & 2 \\
\hline Handdrawing（Zuga) & 2 & 2 & 1 & 1 & 1 & 1 \\
\hline Work Excercise（Sagyō) & 0 & 0 & 1 & 1 & 1 & 1 \\
\hline Business/Industry（Jigyō) & 0 & 0 & 0 & 1 & 2 & 2 \\
\hline Homemaking（Kasei) & 0 & 0 & 0 & 1 & 2 & 3 \\
\hline Total & 24 & 26 & 30 & $34(35)$ & $36(38)$ & $36(38)$ \\
\hline
\end{tabular}

Number inside the bracket shows number of weekly learning hours of girls school. One hour equals to 40 minutes

Source : bunkyō no gaikyō, p.42

\section{c. Comparative Analysis between Japanese and Dutch Curriculum}

Ihave used comparable data between Vervolgschool and the Kokumingakkō to analyses subjects taught under Dutch or Japanese occupation (Table 8). The language education took about 60 hours per week (total hours of all grades) in Non-Malay Vervolgschool. However, Japanese was taught 30 hours per week from grade 1 to grade 6, Malay language (Indonesian language) taught 18 hours, and ethnic/local language was provided 24 hours from grade 1 to 6 . In other words, Kokumingakkō prepared 72 hours for language education as total, which mostly was for Japanese language. This juxtaposing also shows that the weekly learning hours also persisted, except grade 4 of Kokumingakkō in which 2 hours had abolished. More hours were allocated for language education in Vervolgschool.

Moral education (shūshin), history, woodwork/carpenter, work exercise, business/industry and homemaking or housekeeping was added in Kokumingakkô's curriculum as the implication of modern Japanese education system which mostly emphasizes practical daily life rather than theoretical matters. Instead of extending the language education, Japanese system introduced various vocational skills.

Shūsin was abolished in Japan in 1947 (Hara, 2007). The content of shūshin in Indonesia was unclear, but it might be similar with what had been taught in Japan before the war. The first edition of Jinjoshōgakushüshinsho maki 1, the ordinary shüshin textbook for primary school book 1) was published by the 
Monbushō (the Ministry of Education) in 1923, consists of some pictures figuring the morale and attitude regarding teachers, elderly, friends, animals, etc in the first pages. Those pages only consist of pictures without explanation, whilst the first reading written in katakana (Japanese character) describes about tennō (the emperor) is in page 9. Written in details as "Tennō heika banzai" (A cowabunga for the Emperor) and the next page depicts about war and forceful to be a soldier (Anonym, 1923:9-10). Those a bit differed with what recently known as dotoku kyōiku (moral education), where dōtoku emphasize discipline, daily norm and good behavior as a person and member of society.

Table 8 Comparison the Curriculum of Kokumingakkō and Vervolgschool

\begin{tabular}{|c|c|c|c|c|c|c|c|c|c|}
\hline \multirow{3}{*}{ Subject } & \multicolumn{3}{|c|}{ Kokumingakkou } & \multirow{2}{*}{\multicolumn{3}{|c|}{$\begin{array}{c}\text { Malay } \\
\text { National Language }\end{array}$}} & \multirow{2}{*}{\multicolumn{3}{|c|}{$\begin{array}{c}\text { Malay } \\
\text { Foreign Language }\end{array}$}} \\
\hline & \multirow{2}{*}{$4 g r d$} & \multirow{2}{*}{$5 \mathrm{grd}$} & \multirow{2}{*}{ 6grd } & & & & & & \\
\hline & & & & 4grd & 5 grd & $6 \mathrm{grd}$ & 4grd & $5 \mathrm{grd}$ & 6grd \\
\hline \multicolumn{10}{|l|}{ Language Education } \\
\hline Japanese & 6 & 6 & 6 & & & & & & \\
\hline Malay & 4 & 5 & 5 & 0 & 0 & 0 & 4 & 4 & 4 \\
\hline Local language & 3 & 3 & 2 & 8 & 8 & 8 & 7 & 8 & 7 \\
\hline Dutch & & & & 8 & 9 & 10 & 8 & 8 & 10 \\
\hline Sub Total & 13 & 14 & 13 & 16 & 17 & 18 & 19 & 20 & 21 \\
\hline \multicolumn{10}{|l|}{ General Subject } \\
\hline Spirit Education & 2 & 2 & 2 & & & & & & \\
\hline History & 1 & 1 & 1 & & & & & & \\
\hline Geography & 1 & 2 & 1 & 3 & 3 & 3 & 2 & 2 & 2 \\
\hline Arithmetic & 4 & 4 & 4 & 7 & 8 & 8 & 6 & 7 & 6 \\
\hline Science & 1 & 1 & 2 & 3 & 3 & 3 & 2 & 2 & 2 \\
\hline Physical Education & 3 & 3 & 3 & 2 & 2 & 2 & 2 & 2 & 2 \\
\hline Music & 2 & 1 & 1 & 1 & 1 & 1 & 1 & 1 & 1 \\
\hline Callighraphy & 1 & 0 & 0 & 2 & & & 2 & & \\
\hline Woodwork & 2 & 2 & 2 & & & & & & \\
\hline Handdrawing & 1 & 1 & 1 & 2 & 2 & 2 & 2 & 2 & 2 \\
\hline Work Exercise & 1 & 1 & 1 & & & & & & \\
\hline Business/Industry & 1 & 2 & 2 & & & & & & \\
\hline Homemaking & 1 & 2 & 3 & & & & & & \\
\hline Sub Total & 21 & 22 & 23 & 20 & 19 & 19 & 17 & 16 & 15 \\
\hline Total & 34 & 36 & 36 & 36 & 36 & 37 & 36 & 36 & 36 \\
\hline
\end{tabular}

Finally, we can conclude that education under Japanese occupation emphasized moral, body, soul and mind, or mental and character building. It contrasted the education under Dutch occupation which merely fostered academic nurture.

\section{Conclusion}

Japanese military did not directly establish the 6-year primary school system in the early period of the occupation, but at the first step, divided varied Dutch's schools based on course time, one as the 6-year school (Kokumingakkō) and another was the non 6-year primary schools (Shotōkokumingakkō). However, it is 
still unclear whether all Shotōkokumingakkō at the end of occupation had unified as Kokumingakkō or were kept in original form. Before the end of occupation (1944), the schooling situation in Java as reported in bunkyō no gaikyō was still dichotomized.

The school structure proposed by the BP-KNIP in 1946 still used the term Sekolah Pertama together with Sekolah Dasar. Thus we can conclude that primary school system in Indonesia in the early period of independence adopted Japanese system. Then, further study in this field should be brought into deep discourse on whether the content, the purpose and the orientation of learning or the curriculum adopted as well.

Theissue on the decline of the number of primary schools was not established facts in given analyzes. However, this analysis still remains incomplete, since the real statistics of the entire Indonesia in 1942-1944 is unavailable. This study should go further on discussing the implementation of compulsory education at the given time.

The curriculum of primary school before the Japanese occupation was emphasized brain nurturing or academic achievement, where the primary school during Japanese occupation stressing the body and mind nurture, through some practicing and vocational exercise.

\section{REFERENCES}

Djoyonegoro, W. (1996). 50 Tahun Pendidikan Indonesia, Jakarta:B adan Penelitian dan Pengembangan Pendidikan dan Kebudayaan DEPDIKBUD. Hara, K. (2007). Gakkō kyōikukateiron, Tokyo: Gakkobunsya.

Kurasawa, A. (1991).Nanbōgunseikankeisiryō 7 gokuhi Jawa ni okeru bunkyō nogaikyō, Ryūkeishosya: Tokyo

Kurasawa, A.(1992). Nihonsenryōka no jawa nōsan no henyō, Tokyo: Sōshisha.

Lapian, A.B.(1996). 'Personal Reflection on the Japanese Occupation in Indonesia', in Southeast Asian Studies Vol.34, No.1, pp.211-223.

Tilaar, H.A.R. (1995). 50 Tahun Pembangunan Pendidikan Nasional 1945-1995, Jakarta: Grasindo

Dower, J.W. (1986). War Without Mercy: Race and Power in the Pacific War, New York:Pantheon.

Gruhl, W. (2007). Imperial Japan's World War Two, 1931-1945. New Jersey: Transaction Publishers.

Van der Eng, P. (2002). 'Bridging a gap: a reconstruction of population patterns in Indonesia, 1930-61', in Asian Studies Review Vol. 26, No.4, pp.487-509. Retrieved from http://dx.doi.org/10.1080/10357820208713359 on 21st January, 2010.

Thomas, R. M. (1966). 'Educational Remnants of Occupation: The Japanese in Indonesia', in Asian Survey, Vol.6, No.11, pp.630-642. Retrieved from http:// www.jstor.org/stable/2642286? origin=JSTOR-pdf, on $5^{\text {th }}$ July, 2008. 
HISTORIA:

International Journal of History Education, Vol. XI, No. 1 (June 2010)

Poesponegoro, M.D \& N. Notosusanto. (2008).Sejarah Nasional Indonesia VI,Zaman Jepang dan Zaman Republik Indonesia, Jakarta:Balai Pustaka Nasution.(1995). Sejarah Pendidikan Indonesia, Jakarta:Bumi Aksara Mestoko, S.(1985). Pendidikan Indonesia dari Jaman ke Jaman, Jakarta :Balai Pustaka

United Nations, Economic and Social Council, Report of the Working Group for Asia and the Far East, Supp. 10. 1947 